\title{
Aquatic Fungi and Straminipilous Organisms in the Lakes of the Elckie District
}

\author{
Anna Godlewska ${ }^{1 *}$, Bożena Kiziewicz ${ }^{1}$, \\ Elżbieta Muszyńska ${ }^{1}$, Dorota Jankowska ${ }^{2}$ \\ 'Departament of General Biology, Medical University, \\ A. Mickiewicza 2C, 15-222 Białystok, Poland \\ ${ }^{2}$ Department of Statistics and Medical Informatics, \\ Szpitalna 37, 15-295, Poland
}

Received: 4 March 2016

Accepted: 20 April 2016

\begin{abstract}
We analyzed the species composition of fungi and straminipilous organisms in relation to hydrochemical conditions in six lakes within the Ełckie Lake District. The mycological investigations conducted in two vegetative seasons (2014-15) identified 44 species (eight aquatic fungi and 36 straminipilous organisms). The largest number of fungus species were found in lakes Łaśmiady (23), Szarek (22), and Krzywe (20), and the fewest were detected in Ełckie (12), Rajgrodzkie (13), and Dręstwo (14). The diversity of the quantitative and qualitative composition of the mycobiota was probably associated with the content of biogenic compounds and organic substances in the water. The elevated levels of these parameters (lakes: Łaśmiady, Szarek, and Krzywe) stimulated the growth and development of fungi and straminipilous organisms, whereas very high levels of biogenic compounds and organic matter (Lake Ełckie) and their very low content (Lake Dręstwo) had an inhibitory effect.

Among the isolated taxa, there were parasites of amphibians and their spawn, and fish and eggs, including Achlya americana, Ac. polyandra, Saprolegnia parasitica, and S. ferax. Some species included pathogens of crayfish and other aquatic crustaceans such as Myzocytium microsporum, M. zoophthorum, Aphanomyces astaci, and Ap. daphniae. Some fungi appeared to be potentially pathogenic to humans, like Aspergillus niger and Candida tropicalis. Such species as Achlya klebsiana, Ac. prolifera, Leptolegnia caudata, Nowakowskiella elegans, N. macrospora, Pythium inflatum, and Saprolegnia litoralis were common phytosaprobionts.

Statistical analysis of the results was conducted to determine a correlation in the number of the species of fungi and straminipilous organisms with such hydrochemical parameters as the levels of oxygen, carbon dioxide, and biochemical oxygen demand within a five-day period $\left(\mathrm{BOD}_{5}\right)$, chemical oxygen demand (COD), calcium carbohydrate, nitrate nitrogen, phosphates, chlorides, dry mass, dissolved substances, and suspension. The differences noted in the species composition of the mycobiota in the lakes studied resulted from, among other things, the physicochemical properties of water. Such parameters as the contents of oxygen, nitrate nitrogen, phosphates, dry residue, dissolved substances, and suspension showed a positive
\end{abstract}

*e-mail: anna.godlewska@umwb.edu.pl 
correlation, whereas carbon dioxide, $\mathrm{BOD}_{5}, \mathrm{COD}$, calcium carbohydrate, and chlorides correlated negatively with the number of the isolated taxa.

Keywords: fungi, straminipilous organisms, lakes, physicochemical factors, Ełckie Lake District

\section{Introduction}

Fungi and fungus-like organisms constitute a large, diverse, and widespread component of hydro-ecosystems [1-2]. They occur in various types of water reservoirs, both in freshwater and seawater, in running and stagnant waters, and surface and underground waters in a broad spectrum of physicochemical and biological factors. They are involved in the circulation of matter, the flow of energy, and in the maintenance of biological balance.

In natural conditions, most of them are saprotrophs, growing on dead animal and plant remnants. They are rich in hydrolytic enzymes that decompose macromolecular compounds such as polysaccharides, fats, and proteins that help mineralize dead organic matter of both plant and animal origin. Using organic matter for the growth and spread of species, they take part in water self-purification processes and thus naturally prevent eutrophication [3-4].

However, a considerable number of fungi and straminipilous organisms lead a parasitic life and cause diseases among plants, animals, and humans. They frequently cause substantial losses in fishery management and reduce the populations of fish, amphibians, and crayfish [5]. Saprobic fungi may in favorable conditions acquire pathogenic properties and become a potential source of infection [6].

The identification and determination of respective species of aquatic fungi and straminipilous organisms as bio-indicators of water purity in association with environmental conditions are extremely important and are used for hydrosphere monitoring [7].

In our research into species composition of aquatic fungi and straminipilous organisms in relation to the environmental factors in various types of water reservoirs, this time we investigated a few lakes situated within the Ełckie Lake District. Earlier the mycological investigations were conducted in relation to the physicochemical parameters of water in Czeczuga [8].

\section{Material and Methods}

The current mycological investigations were conducted in relation to the physicochemical parameters of water in spring and autumn in 2014-15. Water samples were collected from six lakes within the Ełckie Lake District (Fig. 1):

- Lake Rajgrodzkie is a eutrophic basin near the town of Rajgród, where the water samples were collected. Its surface area ranges from 1,499 to 1,503.2 ha, and maximum depth is $52 \mathrm{~m}$. The banks of the lake are surrounded by pine forest. This lake is used for the farming of northern pike (Esox lucius L.), European perch (Perca fluviatilis L.), burbot (Lota lota L.), bleak (Alburnus alburnus L.), lavaret (Coregonus lavaretus L.), vendace (Coregonus albula L.), and European eel (Anguilla anguilla L.).

- Lake Dręstwo is a mesotrophic basin. The mycological investigations of water were collected near Rybczyzna village. Its surface ranges from 504.2 to 549 ha, and maximum depth is $25 \mathrm{~m}$. Its shoreline includes cultivated fields, swampy meadows, and small forest areas. Fish species living in the lake are vendace (Coregonus albula L.), European smelt (Osmerus eperlanus L.), bleak (Alburnus alburnus L.), lavaret (Coregonus lavaretus L.), bream (Abramis brama L.), roach (Rutilus rutilus L.), and northern pike (Esox lucius L.).

- Lake Krzywe is a eutrophic basin situated near Stare Juchy village. Its surface area amounts to 24 ha and maximum depth is $9.7 \mathrm{~m}$. The banks of the lake are surrounded mainly by fields and meadows. The lake is stocked with tench (Tinca tinca L.) and northern pike (Esox lucius L.).

- $\quad$ Lake Szarek is a eutrophic basin (like Lake Krzywe). The mycological investigations of water were collected near Szarek village. Its surface area is 133 ha and maximum depth is $4.7 \mathrm{~m}$. The lake is surrounded by cultivated fields, meadows, and forest. The flora of the lake includes common reed (Phragmites australis (Cav.) Trin. Ex Steuud), grassweed (Scirpus sylvaticus L.), typha latifolia (Typha latifolia L.), and yellow water-lily (Nuphar luteum L.). Fish species inhabiting the lake are mainly pike (Esox lucius L.), carp (Cypri-

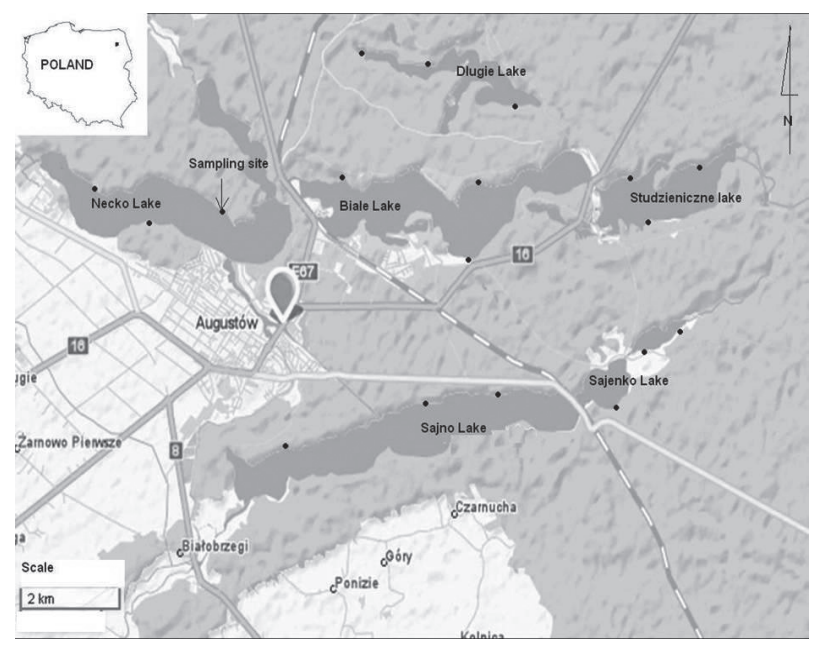

Fig. 1. Study area and sampling sites. 
Table 1. Physical and chemical parameters of water in each lake during spring months (mean of three samples).

\begin{tabular}{|c|c|c|c|c|c|c|}
\hline Factor & $\begin{array}{c}\text { Lake } \\
\text { Rajgrodzkie }\end{array}$ & $\begin{array}{c}\text { Lake } \\
\text { Dręstwo }\end{array}$ & $\begin{array}{l}\text { Lake } \\
\text { Krzywe }\end{array}$ & $\begin{array}{l}\text { Lake } \\
\text { Szarek }\end{array}$ & $\begin{array}{l}\text { Lake } \\
\text { Ełckie }\end{array}$ & $\begin{array}{c}\text { Lake } \\
\text { Łaśmiady }\end{array}$ \\
\hline Temperature $\left({ }^{\circ} \mathrm{C}\right)$ & 7.1 & 5.8 & 6.5 & 7.3 & 8.3 & 5.3 \\
\hline $\mathrm{pH}$ & 7.2 & 7.0 & 7.2 & 7.5 & 8.5 & 7.6 \\
\hline $\mathrm{O}_{2}\left(\mathrm{mg} \mathrm{dm}^{-3}\right)$ & 4.25 & 7.64 & 6.80 & 7.12 & 4.62 & 7.44 \\
\hline $\mathrm{BOD}_{5}\left(\mathrm{mg} \mathrm{dm}^{-3}\right)$ & 0.84 & 0.27 & 0.82 & 0.78 & 0.87 & 0.68 \\
\hline $\operatorname{COD}\left(\mathrm{mg} \mathrm{dm}^{-3}\right)$ & 10.0 & 5.6 & 8.3 & 8.8 & 7.9 & 6.4 \\
\hline $\mathrm{CO}_{2}\left(\mathrm{mg} \mathrm{dm}^{-3}\right)$ & 48.6 & 17.4 & 35.4 & 36.2 & 50.2 & 38.4 \\
\hline Alkalinity in $\mathrm{CaCO}_{3}\left(\mathrm{mval} \mathrm{dm}^{-3}\right)$ & 2.80 & 2.32 & 2.45 & 2.48 & 2.90 & 2.54 \\
\hline $\mathrm{N}-\mathrm{NH}_{3}\left(\mathrm{mg} \mathrm{dm}^{-3}\right)$ & 0.76 & 0.26 & 0.43 & 0.48 & 0.82 & 0.51 \\
\hline $\mathrm{N}-\mathrm{NO}_{2}\left(\mathrm{mg} \mathrm{dm}^{-3}\right)$ & 0.0092 & 0.0010 & 0.0060 & 0.0061 & 0.0078 & 0.0062 \\
\hline $\mathrm{N}-\mathrm{NO}_{3}\left(\mathrm{mg} \mathrm{dm}^{-3}\right)$ & 0.067 & 0.021 & 0.042 & 0.046 & 0.072 & 0.048 \\
\hline $\mathrm{P}^{-\mathrm{PO}_{4}}\left(\mathrm{mg} \mathrm{dm}{ }^{-3}\right)$ & 0.46 & 0.10 & 0.19 & 0.22 & 0.38 & 0.28 \\
\hline Sulphates $\left(\mathrm{mg} \mathrm{dm}^{-3}\right)$ & 38.00 & 12.87 & 24.39 & 26.28 & 38.60 & 19.50 \\
\hline Chlorides $\left(\mathrm{mg} \mathrm{dm}^{-3}\right)$ & 15.0 & 11.0 & 13.0 & 14.0 & 16.0 & 13.8 \\
\hline Total hardness $\left(\mathrm{Ca} \mathrm{mg} \mathrm{dm}{ }^{-3}\right)$ & 41.78 & 58.16 & 47.52 & 50.12 & 43.64 & 49.58 \\
\hline Total hardness $\left(\mathrm{Mg} \mathrm{mg} \mathrm{dm}^{-3}\right)$ & 23.62 & 27.67 & 22.56 & 24.94 & 25.18 & 21.16 \\
\hline $\mathrm{Fe}\left(\mathrm{mg} \mathrm{dm}^{-3}\right)$ & 0.30 & 0.24 & 0.25 & 0.29 & 0.40 & 0.33 \\
\hline Dry residue $\left(\mathrm{mg} \mathrm{dm}^{-3}\right)$ & 290.0 & 104 & 160.0 & 147.0 & 340.0 & 142.0 \\
\hline Dissolved solids $\left(\mathrm{mg} \mathrm{dm}^{-3}\right)$ & 272.0 & 93.0 & 140.0 & 125.0 & 321.0 & 119.0 \\
\hline Suspended solids $\left(\mathrm{mg} \mathrm{dm}^{-3}\right)$ & 18.0 & 11.0 & 20.0 & 22.0 & 19.0 & 23.0 \\
\hline
\end{tabular}

nus carpio L.), Crucian carp (Carassius carassius L.), and tench (Tinca tinca L.) - mainly from restocking.

- $\quad$ Lake Ełckie is more eutrophic than Lake Rajgrodzkie. Situated in the town of Ełk, it is one of the largest and deepest lakes of Poland (surface area is 385 to 400.93 ha and maximum depth is $55.8 \mathrm{~m}$ ). The lake is enclosed by the built-up area of Ełk. Its banks are mainly low and forest-free. The basin is stocked with northern pike (Esox lucius L.), bream (Abramis brama L.), European eel (Anguilla anguilla L.), and European perch (Perca fluviatilis L.).

- Lake Łasmiady is a mesotrophic basin in the central microregion of Ełckie Lake District. The water samples were collected near Malinówka Wielka village. Its surface area is 882-940 ha and maximum depth is $43.7 \mathrm{~m}$. The lake is mainly surrounded by forest and cultivated fields. The fish species living in the basin include ide (Leuciscus idus L.), zander (Sander lucioperca L.), lavaret (Coregonus lavaretus L.), northern pike (Esox lucius L.), wels catfish (Silurus glanis L.), and European eel (Anguilla anguilla L.).

To analyze fungi and straminipilous organisms, three samples of water were collected from each sampling site. Water samples for mycological and physicochemical analysis were obtained from three sites in each lake. They were poured into 0.61 beakers and incubated in a laboratory under conditions resembling those of the natural environment. The baiting method described by Seymour and Fuller [9] was used to isolate the fungi. The following baits were used: crustacean exoskeleton; snake skin; seeds of clover, hemp, and buckwheat; and onion peel. All baits were boiled and rinsed with distilled water several times before use. After three-day incubation, the baits were observed under a microscope (100 and 400x magnification) every 3-5 days for approximately a month. Species were identified according to the following identification keys: Johnson [10], Seymour [11], Dick [12], Batko [3], Pystina [13], and Karling [14]. The systematics of the straminipilous organisms were defined according to Dick [15]. Water samples for physicochemical analysis were collected at a distance of approximately $2 \mathrm{~m}$ from the shore and $50 \mathrm{~cm}$ depth by means of a Ruttner apparatus (2-litre capacity). Water parameters in each reservoir were measured in a laboratory (Tables 1-2) according to the methods proposed by Greenberg et al. [16].

In the statistical analysis (Statistica 10.0 StatSoft), the Wilcoxon paired rank test for two dependent variables was used to compare quantitative variables without normal distribution. Spearman's rank correlation coefficient was also determined. The results were considered statistically significant at $\mathrm{p}<0.05$. 
Table 2. Physical and chemical parameters of water in each lake during autumn months (mean of three samples).

\begin{tabular}{|c|c|c|c|c|c|c|}
\hline & $\begin{array}{c}\text { Lake } \\
\text { Rajgrodzkie }\end{array}$ & $\begin{array}{c}\text { Lake } \\
\text { Dręstwo }\end{array}$ & $\begin{array}{c}\text { Lake } \\
\text { Krzywe }\end{array}$ & $\begin{array}{c}\text { Lake } \\
\text { Szarek }\end{array}$ & $\begin{array}{l}\text { Lake } \\
\text { Ełckie }\end{array}$ & $\begin{array}{c}\text { Lake } \\
\text { Laśmiady }\end{array}$ \\
\hline Temperature $\left({ }^{\circ} \mathrm{C}\right)$ & 12.2 & 10.3 & 12.0 & 13.1 & 14.3 & 11.2 \\
\hline $\mathrm{pH}$ & 7.6 & 7.5 & 7.4 & 7.7 & 8.7 & 8.0 \\
\hline $\mathrm{O}_{2}\left(\mathrm{mg} \mathrm{dm}^{-3}\right)$ & 6.16 & 8.34 & 7.68 & 8.08 & 5.76 & 8.24 \\
\hline $\mathrm{BOD}_{5}\left(\mathrm{mg} \mathrm{dm}^{-3}\right)$ & 1.24 & 0.90 & 1.18 & 1.21 & 1.26 & 0.93 \\
\hline $\operatorname{COD}\left(\mathrm{mg} \mathrm{dm}^{-3}\right)$ & 11.60 & 6.20 & 8.60 & 7.80 & 8.90 & 6.57 \\
\hline $\mathrm{CO}_{2}\left(\mathrm{mg} \mathrm{dm}^{-3}\right)$ & 21.2 & 10.1 & 14.6 & 13.4 & 22.2 & 17.6 \\
\hline Alkalinity in $\mathrm{CaCO}_{3}\left(\mathrm{mval} \mathrm{dm}^{-3}\right)$ & 3.76 & 3.10 & 3.15 & 3.22 & 3.80 & 3.16 \\
\hline $\mathrm{N}-\mathrm{NH}_{3}\left(\mathrm{mg} \mathrm{dm}^{-3}\right)$ & 0.92 & 0.35 & 0.46 & 0.51 & 0.93 & 0.56 \\
\hline $\mathrm{N}-\mathrm{NO}_{2}\left(\mathrm{mg} \mathrm{dm}^{-3}\right)$ & 0.005 & 0.001 & 0.003 & 0.004 & 0.006 & 0.002 \\
\hline $\mathrm{N}-\mathrm{NO}_{3}\left(\mathrm{mg} \mathrm{dm}^{-3}\right)$ & 0.08 & 0.03 & 0.06 & 0.05 & 0.07 & 0.05 \\
\hline $\mathrm{P}^{-\mathrm{PO}_{4}}\left(\mathrm{mg} \mathrm{dm}{ }^{-3}\right)$ & 0.78 & 0.14 & 0.28 & 0.32 & 0.98 & 0.48 \\
\hline Sulphates $\left(\mathrm{mg} \mathrm{dm}^{-3}\right)$ & 12.72 & 3.28 & 10.14 & 11.16 & 14.16 & 9.12 \\
\hline Chlorides $\left(\mathrm{mg} \mathrm{dm}^{-3}\right)$ & 24.0 & 15.6 & 19.6 & 21.2 & 26.0 & 22.8 \\
\hline Total hardness $\left(\mathrm{Ca} \mathrm{mg} \mathrm{\textrm {dm } ^ { - 3 } )}\right.$ & 60.34 & 71.20 & 56.18 & 62.14 & 61.18 & 68.18 \\
\hline Total hardness $\left(\mathrm{Mg} \mathrm{mg} \mathrm{dm}{ }^{-3}\right)$ & 19.96 & 28.16 & 22.34 & 23.68 & 22.14 & 21.64 \\
\hline $\mathrm{Fe}\left(\mathrm{mg} \mathrm{dm}^{-3}\right)$ & 0.33 & 0.23 & 0.18 & 0.20 & 0.46 & 0.35 \\
\hline Dry residue $\left(\mathrm{mg} \mathrm{dm}^{-3}\right)$ & 240.0 & 76.0 & 167.0 & 135.0 & 260.0 & 150.0 \\
\hline Dissolved solids $\left(\mathrm{mg} \mathrm{dm}^{-3}\right.$ ) & 205.0 & 64.0 & 144.0 & 115.0 & 222.0 & 123.0 \\
\hline Suspended solids $\left(\mathrm{mg} \mathrm{dm}^{-3}\right)$ & 35.0 & 12.0 & 23.0 & 21.0 & 38.0 & 27.0 \\
\hline
\end{tabular}

\section{Results}

Our study conducted on six lakes in Warmia-Masuria Province revealed the presence of 44 species, including 36 straminipilous organisms of the class Peronosporymecetes and eight fungal species belonging to the classes of Chytridiomycetes (4), Blastocladiomycetes (2), Ascomycetes (1), and Saccharomycetes (1) (Table 3). The largest numbers of species were detected in Lake Łaśmiady (23) and the smallest in Lake Ełckie (12). The taxa that were most commonly found in all the lakes studied included Catenophlyctis variabilis (except for Lake Dręstwo), Saprolegnia ferax, S. parasitica, and Thraustotheca clavata. The substrate most colonized by fungi and straminipilous organisms was crustacean (Gammarus pulex), whereas onion skin (Allium cepa) and buckwheat seeds (Fagopyrum esculentum) were most rarely colonized by the mycobiota (Table 4).

At $\mathrm{p}=0.50$ no statistically significant differences were noted in the number of fungal species in the lakes between spring and autumn. In both seasons the values were the same, with the median $\mathrm{Me}=7.5\left(\mathrm{Q}_{1}=5, \mathrm{Q}_{2}=9\right)(\mathrm{Fig} 2)$.

The hydrochemical analysis of water samples collected from the respective lakes situated in Ełckie Lake District revealed distinct differences in the parameters studied (Tables 1-2). Oxygen content was higher in au- tumn than in spring in all six water basins. In autumn the oxygen content ranged between 5.76 (Lake Ełckie) and $8.34 \mathrm{mg} \mathrm{dm}^{-3}$ (Lake Dręstwo). The level of carbon dioxide in all the lakes was higher in spring than in autumn, ranging from 17.4 (Lake Dręstwo) to $50.2 \mathrm{mg} \mathrm{dm}^{-3}$ (Lake Ełckie). At the level of significance $(\mathrm{p}=0.007)$ a strong positive correlation was noted $(\mathrm{R}=0.61)$ between the number of fungus species in autumn and oxygen content in water. The content of carbon dioxide showed a moderate negative correlation $(\mathrm{R}=-0.47)$ at the level of significance $(p=0.046)$, with the number of fungus species detected in autumn. $\mathrm{BOD}_{5}$ and $\mathrm{COD}$ in all the study lakes were higher in autumn than in spring. At $p=0.03$, the concentration of $\mathrm{BOD}_{5}$ exhibited a strong negative correlation $(R=-0.51)$ with the number of fungus species isolated in autumn. At $\mathrm{p}=0.004$ there was a high negative correlation $(\mathrm{R}=-0.64)$ between the number of fungus species detected in autumn and COD. The mean level of calcium carbohydrate in all the study lakes was higher in autumn than in spring. In autumn, its highest level was noted in Lake Ełckie (3.80) and the lowest in Lake Dręstwo (3.10). At $\mathrm{p}=0.002$ a strong negative correlation $(\mathrm{R}=-0.67)$ was found between the number of fungus species in autumn and the content of calcium carbohydrate.

Throughout the study period, the lowest contents of nitrate nitrogen and phosphates were observed in Lake 


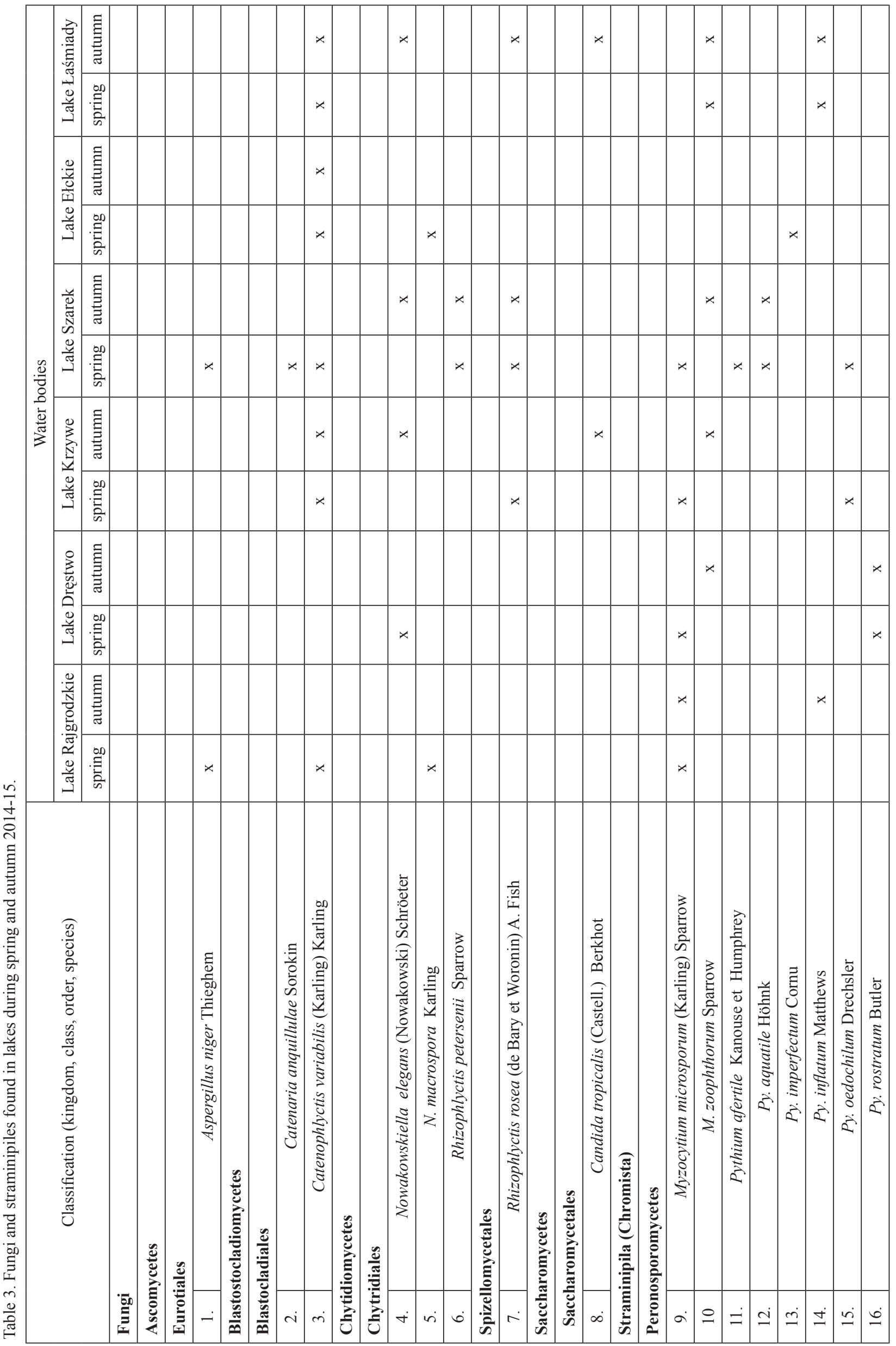




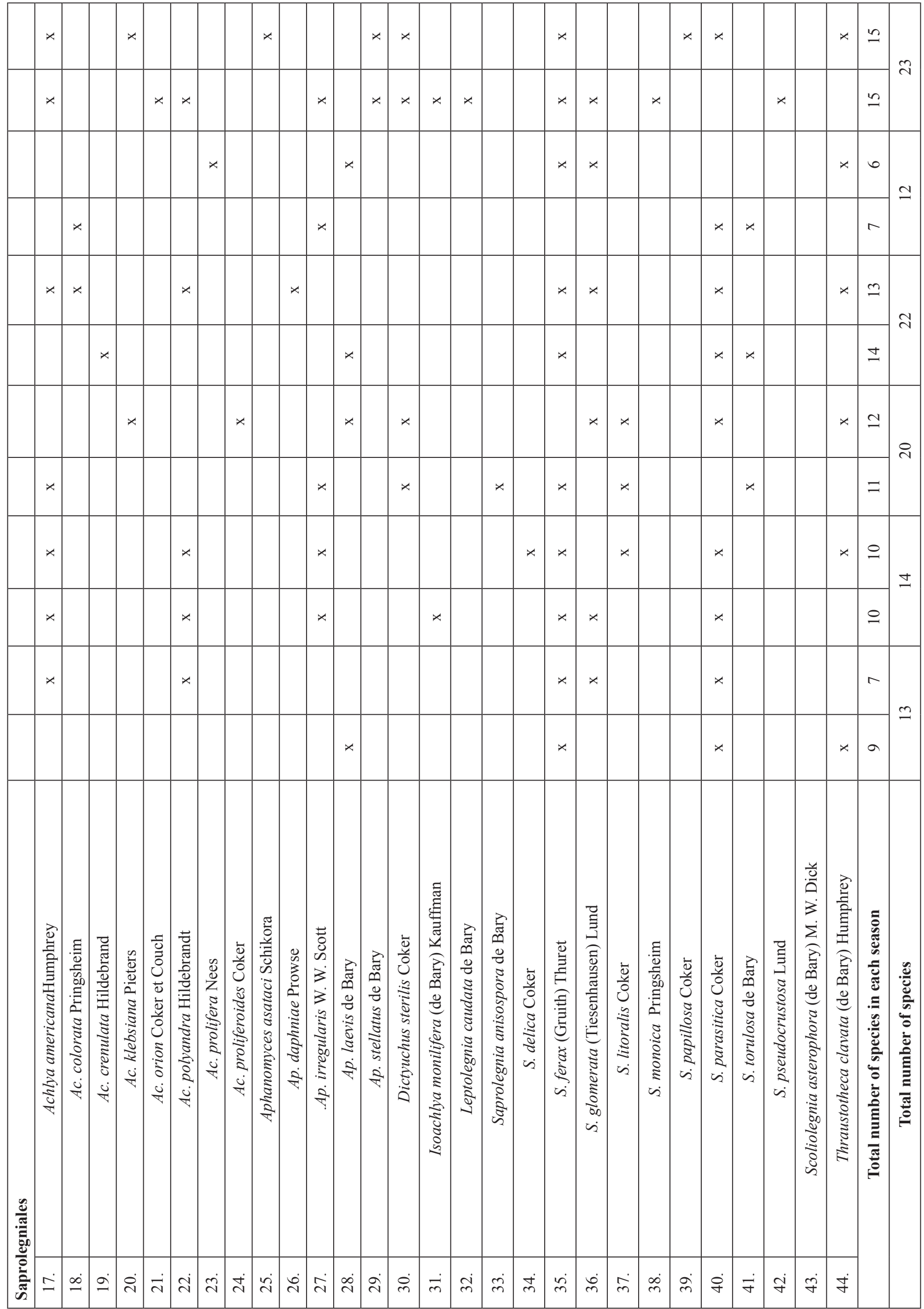


Table 4. Occurrence of fungi and straminipilous organisms on the respective animal and plant substrates.

\begin{tabular}{|c|c|c|}
\hline Animal and plant substrates & Fungi & Number of fungi \\
\hline buckwheat seeds (Fagopyrum esculentum Moench L.) & $17,27,35,36,41$ & 5 \\
\hline clover seeds (Trifolium repens L.) & $4,5,6,7,16,21,27,31,35,36,38,41,42,43$ & 14 \\
\hline crustacean (Gammarus pulex L.) & $1,9,10,14,15,16,17,20,23,25,26,27,28,29,30$, & 22 \\
\hline hemp seeds (Cannabis sativa L.) & $4,5,11,12,13,17,18,19,22,24,32,33,36,37,40$, & 17 \\
\hline onion skin (Allium cepa L.) & 41,44 & 4 \\
\hline snake skin (Natrix natrix L.) & $1,2,3,8,20,27,29,33,37,39$, & 10 \\
\hline
\end{tabular}

Dręstwo and the highest in Lake Ełckie. The level of nitrate nitrogen showed a moderate positive correlation $(\mathrm{R}=0.49, \mathrm{p}=0.040)$ with the number of fungus species isolated in autumn, whereas the content of phosphates exhibited a strong positive correlation $(\mathrm{R}=0.53, \mathrm{p}=0.02)$ with the number of fungus species detected in autumn. The mean level of chlorides in all the study lakes was higher in autumn than in spring. In autumn, their concentration was the highest (26.0) in Lake Ełckie and the lowest in Lake Dręstwo in spring (11.0). At $p=0.046$ this parameter showed a moderate negative correlation $(\mathrm{R}=-047)$ with the number of fungus species in autumn.

Water in Lake Ełckie, Lake Rajgrodzkie, and Lake Krzywe throughout the study period was characterized by the highest content of dry residue and dissolved substances, whereas lakes Dręstwo, Szarek, and Łaśmiady saw markedly lower values of these parameters. At $\mathrm{p}=0.009$ a strong positive correlation $(\mathrm{R}=0.60)$ was found between the number of fungus species detected in autumn and the level of dry residue. At $p=0.014$ there was

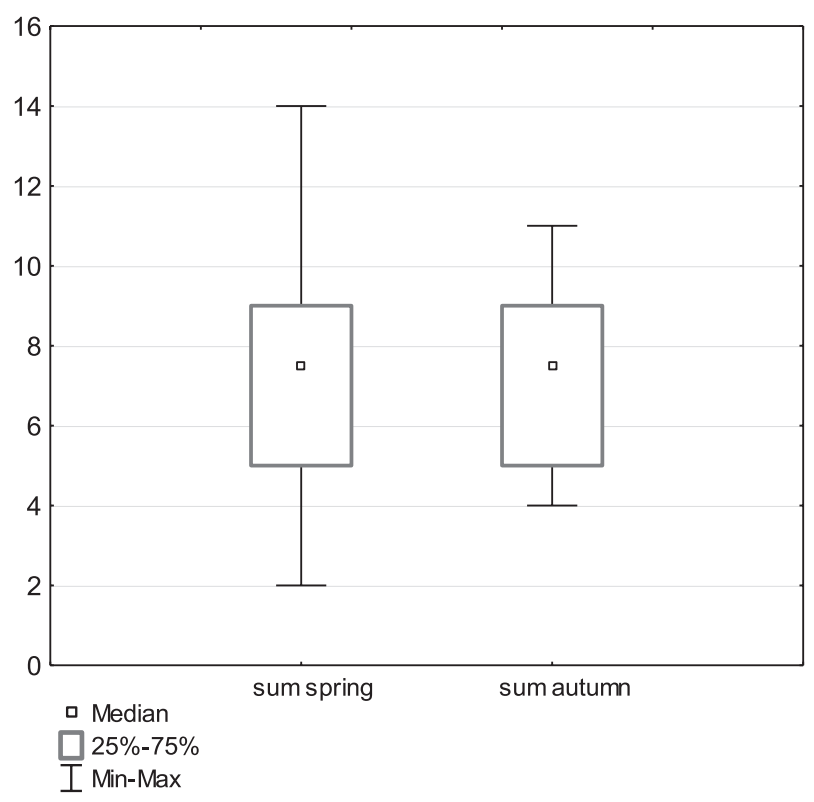

Fig. 2. Relationship between the number of fungi species and straminipilous organisms found in the lakes in spring and autumn. a high positive correlation $(\mathrm{R}=0.57)$ between the number of fungus species in autumn and dissolved substances. At $\mathrm{p}=0.03$ the concentration of suspension exhibited a high positive correlation $(\mathrm{R}=0.52)$ with the number of fungus species in autumn, in contrast to $\mathrm{p}=0.03$ in spring $(\mathrm{R}=0.52)$.

\section{Discussion}

Fungi and straminipilous organisms commonly occur in water reservoirs of various types and have a substantial effect on the functioning of the hydro-ecosystems [17-20]. They play a major role in inland waters, are the source of food for numerous invertebrates, and mineralize organic matter - thus facilitating the process of self-purification.

The current study allowed us to determine species diversity of fungi and straminipilous organisms and how their growth is affected by physicochemical parameters of water in six lakes of the Ełckie Lake District. Most fungal species were isolated from water samples obtained from lakes Łaśmiady (23), Szarek (22), and Krzywe (20). The hydrochemical analysis showed that these water basins are characterized by high content of $\mathrm{O}_{2}$ and moderate concentrations of biogenic compounds (especially nitrates and phosphates). The total content of organic matter was elevated. Literature data suggest that the increased number of fungi and straminipilous organisms as well as their greater biomass are more common in water reservoirs with the increased content of food substances and biogenic compounds if they do not exceed the limit of tolerance $[3,21]$.

The eutrophic water was found in lakes Ełckie and Rajgrodzkie, which is reflected in the low content of dissolved oxygen and high levels of carbon dioxide and biogenic substances.

These lakes also showed the highest level of organic substances, and this might be why they had the smallest number of fungus and fungus-like species (12 and 13, respectively). Many authors believe that water with an increased content of organic and biogenic substances shows lower mycobiotic species diversity [3, 22].

According to physicochemical analysis, Lake Dręstwo was classified as class I purity, i.e. mesotrophic waters. 
This water basin was characterized by the highest content of oxygen, a low level of carbon dioxide, a low concentration of biogenic compounds, and the lowest amount of organic matter. Therefore, only 14 species of fungi and straminipilous organisms were isolated in this lake. Literature data suggest that the too-low content of biogenic substances and organic matter inhibits the activity and growth of these organisms [3, 23].

Among the fungi and straminipilous organisms found in the current study, fungus-like organisms from the kingdom Straminipila (Chromista) were the predominant species. In the lakes involved in the study, the most numerous were species of the genus Saprolegnia (11), Achlya (8), Pythium (6), and Aphanomyces (5). In natural ecosystems, most of these species are common valuable saprobionts playing a role in water purification and thus preventing eutrophication [3-4]. However, some fungi and straminipilous organisms belonging to the abovementioned genera are parasites of plants, animals, and humans. In favorable conditions, saprobionts may acquire pathological properties and be a potential source of infection [6].

Among the species of straminipilous organisms isolated in the current study and belonging to the abovementioned genera, most common were Achlya americana, Ac. polyandra, Aphanomyces irregularis, Saprolegnia ferax, S. glomerata, S. parasitica, and Thraustotheca clavata.

The species of Achlya americana and Ac. polyandra, previously referred to as phyto- and zoosaprobionts, are now known from literature as parasites of crustaceans, fish, and eggs [24-25]. Achlya americana has been reported to have caused mass death of Tilapia mossambicus in a pond at Bhopal University [26]. In our study, Achlya americana was identified in autumn in lakes Rajgrodzkie, Dręstwo, Szarek, and Łaśmiady, and in spring in lakes Dręstwo, Krzywe, and Łaśmiady. Achlya polyandra has frequently been detected on the spawn of rainbow trout (Oncorhynchus mykiss) in Lake Sevan (Armenia), and in various water reservoirs of northeastern Poland, and on the spawn of salmonid species (Salmonidae) in America [27]. In the current study, Achlya polyandra was isolated in autumn from lakes Rajgrodzkie, Dręstwo, and Szarek, and in spring from Dręstwo and Łaśmiady.

The major etiological factor of mycotic diseases are Saprolegniaferax and S. parasitica, which cause substantial losses in fishery management and decrease populations of crayfish and amphibians [28-34]. Throughout the study, these two species were isolated from all the lakes involved. Their mycelia grow most frequently on mechanically damaged tissues of fish and amphibians, and on dead spawn. These two taxa are known to induce thrush [5, 35]. They have caused mycotic infections of eggs and fish of the salmonid family in some fish farms in Hokkaido in Japan [36], and of carp (Cyprinus carpio) in hatcheries in central Iraq [37].

Worthy of note is the finding of two zoosaprobionts, or parasites of aquatic invertebrate: namely Myzocytium microsporum and M. zoophthorum. These taxa were found to grow only on the crustacean Gammarus pulex. These two straminipilous organisms have been isolated many times from various crustacean species and insects in waters of northeastern Poland [38-39].

Rare taxa found in the study lakes include Aphanomyces astaci and Ap. daphniae. Aphanomyces astaci contribute to the reduction in the population of crustaceans and other aquatic arthropods [40-41], whereas Ap. daphniae has been known as a parasite of Cladocera, Copepoda, and Rotatoria [40]. In the study lakes, these two species were identified only on the crustacean Gammarus pulex.

Interestingly, we isolated Catenophlyctis variabilis. This taxon has been reported in literature as a widespread saprobiont found on various keratinous substrates [14]. It grows on human skin, hair, nails, animal fur, feathers, and hoof nails, and is potentially pathogenic to humans. Keratinophylic pathogenic fungi have been observed in various types of water basins and watercourses $[5,42]$. We found this fungus only on snake skin (Natrix natrix).

Aspergillus niger and Candida tropicalis, fungi potentially pathogenic to humans, were detected in the lakes. Aspergillus niger was found on crustaceans (Gammarus pulex) only in spring in eutrophic Lake Rajgrodzkie and in eutrophic Lake Szarek, whereas Candida tropicalis was isolated on snake skin (Natrix natrix) only in autumn from the mesotrophic lakes Krzywe and Łasmiady. These species are responsible for opportunistic mycoses and have been found to inhabit human skin; the alimentary, genitourinary, and respiratory tracts; and other tissues and organs [43-44].

The presence of numerous phytosaprobionts in the water reservoirs studied also is interesting. They are able to secrete hydrolytic enzymes that mineralize vegetative organic matter [45-47]. This group includes Achlya klebsiana, Ac. prolifera, Leptolegnia caudata, Nowakowskiella elegans, N. makrospora, Pythium inflatum, and Saprolegnia litoralis. Some of them - especially species of the genera Pythium and Saprolegnia - can be obligate or facultative parasites of various plants submerged in water [48].

\section{Conclusions}

The hydrochemical analysis of lake water within Ełckie Lake District involved in the current study revealed differences in physicochemical parameters, which affected the species number and composition of straminipilous organisms and aquatic fungi. High oxygen content and the elevated level of organic matter and biogenes - even within the limits of tolerance - may have a positive effect on growth and numbers of fungi. High levels of carbon dioxide and too low-concentrations or too high contents of bio-genes (especially nitrate nitrogen and phosphates) limited the occurrence and activity of fungi and straminipilous organisms in the water reservoirs studied. 


\section{References}

1. VORONIN L.V. Zoosporic fungi in freshwater ecosystems. Inland Water Biol. 4, 341, 2008.

2. WURZBACHER CH. M., BÄRLOCHER F., GROSSART H. P. Fungi in lake ecosystems. Aquat. Microb. Ecol. 59, 125, 2010 doi: 10.3354/ame01385

3. BATKO A. Hydromycology - an overview. PWN, Warszawa, 5, 1975 [In Polish].

4. PASCOAL C., CÁSSIO F. Linking fungal diversity to the functioning of freshwater ecosystems. In: SRIDHAR K.R., BÄRLOCHER F, HYDE K.D. (eds) Novel techniques and ideas in mycology. 1, 2008.

5. GODLEWSKA A., KIZIEWICZ B., MUSZYŃSKA E., Mazalska B. Aquatic fungi and straminipilous organisms of the Augustowska Primeval Forest, Poland. Oceanol. Hydrobiol. St. 4, 451, 2013.

6. LEPÉRE C., DOMAIZNN I., DEBROAS D. Unexpected importance of potential parasites in the composition of the freshwater small-eukaryote community. Appl. Environ. Microbiol. 74, 2940, 2008.

7. GODLEWSKA A., KIZIEWICZ B., MUSZYŃSKA E., MAZALSKA B. Aquatic fungi and heterotrophic straminipiles from fishponds. Pol. J. Environ. Stud. 3, 615, 2012.

8. CZECZUGA B. Hydromycoflora of thirty-one lakes in Ełk Lake District and adjacent waters with reference on the chemistry of the environment. Acta Mycol. 30 (1), 49, 1995.

9. SEYMOUR R. L., FULLER M. S. Colletion and isolation of water molds (Saprolegniaceae) from water and soil. In : Fuller M. S., Jaworski A. (eds). Zoosporic Fungi in Teaching and Research. Southeastern Publishing, Athens. 125, 1987.

10. JOHNSON T.W.Jr. The genus Achlya morphology and taxonomy. University of Michigan Press, Ann Arbor, 1, 1956.

11. SEYMOURR. L. The genus Saprolegnia. Nova Hedwigia. 1-2, 1, 1970.

12. DICK M.W. Keys to Pythium. College Estate Management Whiteknights, Reading, U. K. 64, 1990.

13. PYSTINA K.A. Genus Pythium Pringsh. In: Melnik W.A. (eds). Definitorium Fungorum Rossiae. Classis Oomycetes. Sankt Petersburg, Nauka, pp. 5-125, 1998 [In Russian].

14. KARLING J.S. Chytridiomycetarum Iconographia. An Illustrated and Brief Descriptive Guide to the Chytridiomycetes. Lubrecht and Cramer, Vaduz, 414, 1977.

15. DICK M.W. The Peronosporomycetes. In: MCLAUGHLIN D.J., MCLAUGHLIN E.G., LENKE P. A. (eds). The Mycota VII. Part A. Systematics and Evolution. Springer- VerlagBerlin-Heidelberg-New York, 39, 2001.

16. GREENBERG A.L., CLESCERI L.S., EATON A.D. Standard Methods for the Examination of Water and Wastewater. American Public Health Assotiation, Washington, 1193, 1995.

17. PABST S., SCHEIFHACKEN N., HESSELSCHWERDT J., WANTZEN K. Leaf litter degradation in the wave impact zone of a prealpine lake. Hydrobiologia 613,117, 2008.

18. DIGBY A.L., GLEASON F.H., McGEE P.A. Some fungi in the Chytridiomycetes can asymilate both inorganic sources of nitrogen. Fungal Ecol. 3, 261, 2010.

19. KRAUSS G-J., SOLÉ M., KRAUSS G., SCHLOSSER D., WESENBERG D \& BÄRLOCHER F. Fungi in freshwaters - ecology, physiology and biochemical potencial. FEMS. Microbiol Rev. 35, 620, 2011. doi: 10.1111/j. 15746976.2011.00266

20. MARANO A.V., PIRES-ZOTTARELLI C.L.A., BARRERA M.D., STECIOW M.M., GLEASON F.H. Diversity, role in decomposition, and succession of zoosporic fungi and straminipiles on submerged decaying leaves in a woodland stream. Hydrobiologia. 659, 93, 2011.

21. GÓRNIAK A., WIĘCKO A., CUDOWSKI A. Fungi biomass in lowland rivers in North-Eastern Poland: effects of habitat conditions and nutrient concentration. Pol. J. Ecol. 4, 748, 2013.

22. GODLEWSKA A., KIZIEWICZ B., MUSZYŃSKA E., MAZALSKA B. Fungi and straminipilous organisms found in ponds Białystok. Pol. J. Environ. Stud. 3, 369, 2009.

23. MUSZYŃSKA E., KIZIEWICZ B., GODLEWSKA A., MILEWSKI R. Fungi and straminipilous organisms growing In the Narew river and its Chojen tributaries in Ne Poland. Pol. J. Environ. Stud. 2, 401, 2014.

24. KIZIEWICZ B., NALEPA T.F. Some fungi and water molds of lake Michigan with amphasis on those associated with the benthic amphipod Diporeia sp. J. Great Lakes Res. 34, 774, 2008.

25. CZECZUGA B., SEMENIUK A., CZECZUGASEMENIUK E. Straminipiles fungi growing on the alevins of the Nile tilapia in limnologically and trophically different water bodies. Afr. J. Res. 18, 1346, 2014.

26. REKHA CHAUHAN. Fungal attack on Tilapia mossambicus in culture pond, leading to mass mortality of fishes. Int. J. Phram. Sci. Rev. Res. 7, 2014.

27. CZECZUGA B., SEMENIUK-GRELL A., CZECZUGASEMENIUK E. Growth of mycotal species on the eggs of Cyprinus carpio in limnologically and trophically different water bodies. Afr. J. Res. 6, 482, 2015.

28. PETRISKO J.E., PEARL CH.A., PILLIOD D.S., SHERIDAN P.P., WILLIAMS CH.F., PETERSON CH.R., BURY B.R. Saprolegniaceae identified on amphibian eggs throughout the Pacific Northwest, USA, by internal transcribed spacer sequences and phylogenetic analysis. Mycologia. 2, 171, 2008.

29. CZECZUGA B., BARTEL R., SEMENIUK A., CZECZUGA-SEMENIUK E., MUSZYŃSKA E., GODLEWSKA A., MAZALSKA B., GROCHOWSKI A. Straminipilous organisms (Mycota) growing on the eggs of Atlantic salmon (Salmo salar L.) entering Polish rivers for spawning or reared in fresh water. Trends Comp. Biochem. Physiol. 15, 73, 2011a.

30. CZECZUGA B., CZECZUGA-SEMENIUK E., SEMENIUK A. Microfungi-like oeganisms developing on the eggs of pink salmon Oncorhynchus gorbuscha. Cur. Trends Microbiol. 7, 21, 2011b.

31. CZECZUGA B., CZECZUGA-SEMENIUK E., SEMENIUK A., SEMENIUK A., MUSZUŃSKA E. Zoosporic fungi and fugus-like organisms growing on the eggs of four species of sturgeonoid fish (Acipenseriformes). Trends Comp. Biochem. Physiol. 15, 83, 2011c.

32. CZECZUGAB., CZECZUGA-SEMENIUK E., SEMENIUK A., SEMENIUKJ. Straminipiles (Oomycota) developing on the eggs of an catfish, Claris gariepinus Burchell in water bodies of Poland. Afr. J. Microbiol. Res. 20, 2378, 2013.

33. GOZIAN R.E., MARSHALL W.L., LILJE O., JESSOP C.N,GLEASON F.H., ANDREOU D. Curent ecological understanding of fungal-like pathogens of fish; what lies beneath? Frontiers in Microbiol. 5 (62), 1, 2014.

34. MONA S. ZAKI, OLFAT M. FAWAZI. Saprolegnia parasitica in fish (Review). Life Sci. J. 2, 156, 2015.

35. KIZIEWICZ B., MUSZYŃSKA E., GODLEWSKA A. Occurrence fungi and funguj-like organisms potentially pathogenic for fish eggs in differential waters of Podlasie province, Poland. Wulffenia. 7, 464, 2015. 
36. MORTADA M.A., HUSSEIN M.M., HATAI K., NOMURA T. Saprolegniosis in salmonids and their egss in Japan. J. Wild. Dis. 1, 204, 2001.

37. HABIB K.A., AL-MUKHTAR E.A., AL-SHAMMAN R.H. Characterization of Saprolegnia spp. Isolates of from infected eggs, fry and adults of common carp Cyprinus carpio L. based on molecular data in Al-Manahel and Al-Wahda fish hatcheries, in middle of Irag. J. Biot. Lett. 1, 72, 2014.

38. CZECZUGA B., KOZŁOWSKA M., GODLEWSKA A., VELU.S.C. Moina makrospora (Straus): A plankton crustacean as a vector for fungus-like fish parasites. Turk J. Zool. 32, 19, 2008.

39. CZECZUGA B., SEMENIUK A., GODLEWSKA A., CZECZUGA-SEMENIUK E., VELU C.S. Dead specimens of shrimp Streptocephalus dichotomus (Crustacea) as vectors of mycosis-inducing in fish aquacultures. Current Trends in Ecology.3, 54, 2012.

40. CZECZUGA B., KOZŁOWSKA M., GODLEWSKA A. Zoosporic aqutic fungi growingon dead specimens of 29 freshwater crustacean species. Limnologica. 32, 180, 2002.

41. CESARE C., NICOLA F., DANIELA Z., MOURILIA M., ALEBSANDRA P., LUCIANO R., ROSSELLA L. Confirmation of crayfish plague in Italy: detection of Aphanomyces astaci in white clawed crayfish. Dis. Aquat. Org. 89, 265, 2010.
42. KIZIEWICZ B., KOZŁOWSKA M., GODLEWSKA A., MUSZYŃSKA E., MAZALSKA B. Water fungi occurrence in the River-bath Jurowce near Białystok. Wiad. Parazytol. 50, 143, 2004 [In Polish].

43. DYNOWSKA M. Yeast-like fungi possesing bio-indicator properties isolated from the Łyna River. Acta Mycol. 32, 279, 1997 [In Polish].

44. MEDEIROS A., KOHLER L., HAMDAN J., MISSAGIA B., BARBOSA F., ROSA C. Diversity and antifungal susceptibility of yeasts from tropical freshwater environments in southeastern Brazil. Water Res. 42, 392, 2008.

45. CZECZUGA B., MUSZYNSKA E., GODLEWSKA A., MAZALSKA B. Aquatic fungi and fungus-like organisms growing on seeds of 131 plant taxa. Nova Hedwigia. 89, 451, 2009.

46. CZECZUGA B., GODLEWSKA A., MAZALSKA B., MUSZYŃSKA E. Diversity of aquatic fungi and fungus-like organisms on fruits. Nova Hedwigia. 90, 123, 2010.

47. CZECZUGA B., GODLEWSKA A., CZECZUGASRMENIUK E., SEMENIUK A., MUSZYŃSKA E. Influence on mycotal species diversity by different stem part sof submerged aquatic plants that inhibit the growth of aquatic organisms. Nova Hedwigia. 3-4, 335, 2015.

48. MASSOUD M. Mycoflora associated with aquatic plants in ponds and lakes central west of Florida. USA. Sci. Res. Rep. 1, 1, 2012. 